\title{
Somut Olmayan Kültürel Miras Konulu Bilimsel Yayınların Veri Görselleştirme Tekniği ile Bibliyometrik Analizi
}

\author{
Ahmet Baytok 1 (D) Mehmet Boyraz 2 iD Berkan Başar ${ }^{3 *}$ iD \\ ${ }^{1}$ Afyon Kocatepe Üniversitesi, Turizm Fakültesi, Afyonkarahisar, Türkiye, ahmetbaytok@aku.edu.tr, ORCID: 0000-0002-5826-7694 \\ ${ }^{2}$ Afyon Kocatepe Üniversitesi, Turizm Fakültesi, Afyonkarahisar, Türkiye mboyraz@aku.edu.tr, ORCID: 0000-0001-6755-1999 \\ ${ }^{3}$ Afyon Kocatepe Üniversitesi, Sosyal Bilimler Enstitüsü, Afyonkarahisar, Türkiye berkan_basar@hotmail.com, ORCID: 0000-0001-7516-9474
}

Öz

Araştırmanın amacı, Somut Olmayan Kültürel Miras (SOKÜM) alanında yapılmış tez, makale ve bildirilerin bibliyometrik olarak değerlendirilmesidir. Araştırma Yükseköğretim Kurulu (YÖK) Ulusal Tez Merkezi, Dergipark Akademik ve YÖK Akademik veri tabanlarında yer alan SOKÜM konulu bilimsel yayınları kapsamaktadır. Araştırma örneklemi, 27-31 Ağustos 2020 tarihleri arasında yapılan taramalar sonucunda ulaşılan 54 lisansüstü tez, 136 makale ve 21 bildiri çalışması olmak üzere 211 akademik yayından oluşmaktadır. Yayınların değerlendirilmesinde sıklık ve yüzde analizleri birlikte kullanılmış ve çeşitli bibliyometrik parametreler açısından çapraz tablolar halinde ele alınmıştır. Verilerin görselleştirilmesinde ise Tableau yazılımı kullanılmıştır. Araştırma sonucunda, SOKÜM ile ilgili yayınların özellikle 2015 yılı sonrasında artmaya başladığı görülmüştür. SOKüM ile ilgili akademik çalışmaların; en fazla Türk Halk Bilimi Anabilim Dalı tarafından gerçekleştirildiği, yayın dili ve yararlanılan referans kaynakların niteliği bakımından büyük bir çoğunluğunun Türkçe olduğu belirlenmiştir. Yayınların içerdikleri SOKÜM değerleri/unsurları bakımından ele aldığı en yoğun unsurun el sanatları olduğu ve en çok SOKÜM'ün korunması alanında çalışmaların yapıldığı tespit edilmiştir.

Anahtar Kelimeler: Somut Olmayan Kültürel Miras, Turizm Alanyazını, Bibliyometrik Analiz, Veri Görselleştirme, Tableau

\section{Bibliometric Analysis of Intangible Cultural Heritage Scientific Publications with Data Visualization Technique}

Cilt 5, Sayı 2, 2021 ss. $246-262$

\section{Abstract}

The aim of this research is to bibliometric evaluation of theses, articles and papers made in the field of intangible cultural heritage (ICH). The research covers scientific publications on ICH in YÖK National Thesis Center, Dergipark Academic and YÖK Academic database. The research sample consists of 211 academic publications, including 54 graduate theses and 136 articles and 21 reports which were obtained as a result of the searches conducted between 27-31 August 2020. In evaluation of these publications, frequency and percentage analysis were used together and were discussed in cross tables in terms of various bibliometric parameters. Tableau software was used for the visualization of the data. As a result of the research, it was observed that the publications related to ICH started to increase especially after 2015. It is seen that the academic studies on ICH are mostly carried out by the Department of Turkish Folklore, and the language of most of the publications and their reference sources are Turkish. It has been determined that the most intense element that the publications deal with in terms of $\mathrm{ICH}$ values/elements are handicrafts and the most studies are carried out in the field of protecting $\mathrm{ICH}$.

Keywords: Intangible Cultural Heritage, Tourism Literature, Bibliometric Analysis, Data Visualization, Tableau
Research Article

Vol 5, No 2, 2021

pp. 246-262

Received : 09.04.2021

Revision1: 23.05 .2021

Accepted: 31.05 .2021

\section{Önerilen Atıf/Suggested Citation}

Baytok, A., Boyraz, M. ve Başar, B. (2021). Somut Olmayan Kültürel Miras Konulu Bilimsel Yayınların Veri Görselleştirme Tekniği ile Bibliyometrik Analizi. Güncel Turizm Araştırmaları Dergisi, 5(2), 246-262.

**Sorumlu yazar e-posta: berkan_basar@hotmail.com 


\section{GíRiş}

Belirli bir alanda gerçekleştirilmiş bilimsel çalışmaların incelenmesi alanın teorik, kurumsal ve kavramsal çerçevesinin tespit edilmesi, alandaki farklı, yeni eğilimlerin ortaya çıkarılabilmesi ve eksik olan yönlerin belirlenmesini, diğer bir ifade ile ilgili alanın profilinin ortaya çıkarılmasını sağlar. Bir alanın profilini ortaya koymak amaçlı yapılan çalışmalar, aynı zamanda araştırmacılara yeni araştırmaların geliştirilmesi olanağı sağlar (Hall, 1991: 521). Bibliyometri; herhangi bir alandaki çalışmaların, çeşitli özelliklerini niceliksel analizlerle inceleyen, matematiksel ve istatistiksel yöntemlerin kitaplar ve diğer benzeri iletişim ortamlarına uygulanmasını sağlayan bir yöntemdir (Pritchard, 1969: 348; Toksöz ve Birdir, 2016: 76). Bibliyometrik çalışmalar, herhangi bir konudaki en verimli araştırmaları belirleyen ve bu araştırmalar arasındaki etkileşimi ortaya çıkarabilen çalışmalardır (Al,2008:19). Birçok farklı disiplin ve araştırma konularında yoğun olarak tercih edilen bibliyometri yöntemi (Lawani, 1981; Ağaoğlu, 1985; Potter, 1988; Hoffman ve Holbrook, 1993; Kozak, 2000; Toksöz ve Birdir, 2016; Çelebi vd., 2020) SOKÜM alanında da yapılmış çalışmaların profilini ortaya koymak adına yararlanılan bir tekniktir.

Birleşmiş Milletler Eğitim, Bilim ve Kültür Örgütü (United Nations Educational, Scientific and Cultural Organization) (UNESCO)'nün 17 Ekim 2003 tarihinde gerçekleştirilen 32. Genel Konferansı'nda kabul edilen Somut Olmayan Kültürel Mirasın Korunması Sözleşmesini, Türkiye 19 Ocak 2006 tarihli ve 5448 Sayılı Somut Olmayan Kültürel Mirasın Korunması Sözleşmesi'nin Uygun Bulunduğuna Dair Kanunla kabul etmiştir (KTB, 2020a). Bu kapsamda, Türkiye'de akademik anlamda yapılan çalışmaların geçmişinin yaklaşık 15 yıllık bir döneme dayandığı görülmektedir. Somut Olmayan Kültürel Miras (SOKÜM), UNESCO tarafından; toplulukların, grupların ve kimi durumlarda bireylerin, kültürel miraslarının bir parçası olarak tanımladıkları uygulamalar, temsiller, anlatımlar, bilgiler, beceriler ve bunlara ilişkin araçlar, gereçler ve kültürel mekânlar biçiminde tanımlanmaktadır (KTB, 2020b). Toplumların sahip olduğu maddi ve manevi değerler hakkında bilgi sahibi olabilmek adına SOKÜM gerek sosyal gerekse de fen bilimlerinde birçok bilim dalı tarafından, araştırma konusu olmuştur. İlgili alanyazınında gerçekleştirilmiş olan tez, makale ve bildiri çalışmaları SOKÜM'ın birçok bilim dalı açısından, ortak çalışma konusu olduğunu ortaya çıkarmaktadır. Birçok farklı disiplin tarafından ele alınan SOKÜM'ın, hangi bilim dalları tarafından daha çok ele alındığı, araştırmalarda kullanılan yöntemlerin neler olduğu, ilgili alanın kaynakçasının çeşitliliği gibi unsurların belirlenebilmesi ve alanın mevcut profilini ortaya çıarabilmek adına bibliyometrik çalışmalar yapmak son derece önem arz etmekte ve konunun gelişimine oldukça fayda sağlamaktadır. SOKÜM ile ilgili Tuna ve Saral (2018) tarafından yapılan ve sadece eğitim bilimleri alanını kapsayan tek bir bibliyometrik çalışma yer almaktadır. İlgili çalışmada SOKÜM ile ilgili tek bir bilim dalı çerçevesinde bibliyometrinin oluşturulduğu görülmektedir. Bu çalışmada Türkiye'de SOKÜM ile ilgili farklı anabilim dallarında (halk bilimi, turizm, eğitim bilimleri, mimarlık vb.) yapılan, tez, makale ve bildiri türünde yayınlanmış çalışmaların bibliyografisi çeşitli değişkenler açısından incelenmiştir. Çalışmada YÖK, Ulusal Tez Merkezi, Dergipark 
Akademik ve YÖK Araştırma Veri Tabanında yer alan, SOKÜM konulu bilimsel yayınlar bibliyometrik parametreler açısından değerlendirilmeye çalışılmıştır.

\section{Kavramsal Çerçeve}

Kültür; tarihsel, toplumsal gelişme süreci içerisinde oluşturulan bütün maddi ve manevi değerler ile bunları meydana getirmede, sonraki nesillere aktarmada kullanılan, insanın doğal ve toplumsal çevresine egemenliğinin ölçüsünü gösteren araçların bütünüdür (TDK, 2020a). Kültür bir toplumu diğer toplumlardan farklı kılan, inançları, örf ve adetleri, davranışları ile onun kimliğini oluşturan ve geçmişten beri değişerek süregelen insan eli ile yaratılmış maddi ve manevi bütün unsurları içermektedir (Demirel ve Kaya, 2009: 3; Boas, 2012: 59). Geçmişten günümüze aktarılarak ilerleyen kültürel değerler miras olarak farklı nesillere aktarılarak, sürdürülebilen bir nitelik taşımaktadır. Bir neslin kendinden sonra gelen nesle bıraktığı değer olarak ifade edilebilen (TDK, 2020b) miras, kültürel miras olarak değerlendirildiğinde, geçmiş nesillerden miras kalan, bireysel ve toplumsal olarak anlamlar yüklenen ve bundan dolayı korunması gerekli olan, farklı dönemlerde yaşayan toplulukların sosyal, kültürel, ekonomik ve siyasal yaşamlarıyla ilgili en somut bilgiler veren değerler olarak tanımlanmıştır (Hereduc, 2005: 12; Madran ve Özgönül, 2005: 73). Hereduc (2005)'un yapmış olduğu tanımda somut bilgiler veren değerler olarak bahsedilen kültürel miras, özellikle günümüzde somut ve somut olmayan kültür olarak uluslararası düzeyde kabul görmektedir (Ahmad, 2006: 298). SOKÜM, UNESCO tarafından toplulukların, grupların ve kimi durumlarda bireylerin kültürel miraslarının bir parçası olarak tanımladıkları uygulamalar, temsiller, anlatımlar, bilgiler, beceriler ve bunlara ilişkin araçlar, gereçler ve kültürel mekanlar olarak tanımlanmaktadir (KTB, 2020c).

UNESCO 17 Ekim 2003 tarihinde Paris'te düzenlenen 32. Genel Konferansı'nda Somut Olmayan Kültürel Miras Sözleşmesi'ni kabul etmiştir. Türkiye 19 Ocak 2006 tarihli ve 5448 Sayılı Somut Olmayan Kültürel Mirasın Korunması Sözleşmesi'nin Uygun Bulunduğuna Dair Kanunla bu sürece dahil olmuştur (KTB, 2020a). Türkiye'nin SOKÜM Sözleşmesini kabul etmesinin ardından özellikle birçok sosyal bilim ve sanat alanında SOKÜM önemli bir akademik çalışma unsuru olarak değerlendirilmiştir. Başta halkbilimi olmak üzere eğitim, edebiyat, müzecilik, mimarlık, antropoloji, el sanatları ve turizm alanlarında somut olmayan kültürel mirasa yönelik Türkiye' de birçok çalışma ortaya çıkmıştır.

Günümüzde SOKÜM unsurlarının kültür turizmi kapsamında önemli turistik değerler olarak kabul edildiği görülmektedir. Kültürel deneyimler, somut olmayan kültürel miras unsurlarına yönelik ilgiyi artırmakta ve kültür turizmini daha tercih edilebilir kılmaktadır (Ar, 2015:32). Bu durum, araştırmacıların SOKÜM ve turizm arasındaki ilişkiye yönelik çalışmalar yaptığını ve turizm alanı özelinde SOKÜM ile ilgili bildiri, makale, tez gibi bilimsel yayınların nitelik ve nicelik bakımından giderek arttığını göstermektedir. Turistlerin destinasyon seçiminde kültürel unsurların önemli bir rolü vardır. Özellikle turistik destinasyonlarda çekicilik unsuru olarak görülen SOKÜM değerlerinin korunması, sürdürülebilirliği ve tanıtımının yapılması 
konusunda akademik çalışmaların yapılan araştırmalar dahilinde 2010 yılı itibariyle yoğunlaştı̆̆ı görülmektedir (Toksöz ve Birdir, 2016; Çelebi vd., 2020). Bu çalışma alanlarından biri de turizm ve SOKÜM ilişkisine yönelik yapılmış olan bibliyometrik araştırmalardır.

Bibliyometrik araştırmalarda, araştırmaların yayın türü, yayın yeri, yayın dili, yazarı, araştırma alanı \konusu, referans kaynakları, anahtar kelimesi/leri, sayfa sayısı vb. birçok parametre bulunmaktadır (Sandıkcı vd., 2018: 2). Bu bağlamda bibliyometrik araştırmalar ilgili alandaki akademik çalışmalar hakkında önemli bilgiler sunmaktadır. Bibliyometrik çalışmaların tarihsel gelişimine bakıldığında, belirli bir disiplinin gelişimini ya da mevcut durumunu tespit ederek, öneriler sunmayı amaçlayan ilk bibliyometrik çalışmanın 1917 yılında Cole ve Eales tarafından ortaya çıktığı görülmektedir (Çelebi, Çiftsüren ve Dilek., 2020: 11). Cole ve Eales tarafından yapılan bu çalışma 1550-1860 yılları arasında anatomi alanında yayınlanmış olan araştırmaları içermektedir (Cole ve Eales, 1917). Türkiye' de ise bibliyometrik bağlamda yapılan ilk çalışma 1970 yılında Özinönü tarafından yayınlanan ve fizik, kimya, biyoloji, matematik, astronomi ve yer bilimleri alanlarının verimliliğinin ölçüldüğü "Growth in Turkish Positive Basic Sciences" adlı çalışma kabul edilmektedir (Durmuş ve Kaya, 2018; Hotamışlı ve Erdem, 2014; Polat vd., 2019). Türkiye'de kültürel miras ile ilgili yapılan bibliyometri çalışmalarına bakıldı̆̆ında, Çelebi vd. (2020) 1990 ve 2020 Şubat dönemi arasındaki kültürel miras konulu tezleri analiz ettiği ve özellikle 2010 yılı itibariyle ilgili konu hakkında yazılan tezlerin artış gösterdiği, en fazla çalışılan bilim dallarının mimarlık, mühendislik ve turizm olduğu ve en çok yüksek lisans tezlerinde konunun tercih edildiği sonuçlarına varmışlardır. Kültürel miras ile ilgili benzer bir diğer çalışma ise Toksöz ve Birdir (2016)'in yapmış oldukları turizm özelinde yazılan lisansüstü tezlere yönelik bibliyometrik çalışmadır. $\mathrm{Bu}$ çalışmada da araştırmacılar 2010 yılı itibariyle konuya olan ilginin arttı̆̆ı ve doktoraya oranla yüksek lisans tez çalışmalarında daha fazla yoğunluğun olduğunu tespit etmişlerdir. Her iki çalışma da örneklemlerini lisansüstü tezlerle sınırlı tutmuştur. Türkiye'de SOKÜM ile ilgili bibliyometrik çalışma Tuna ve Saral (2018)'in çalışmasıyla sınırlı kalmıştır. İlgili çalışma Somut Olmayan Kültürel Mirasın Korunması Sözleşmesi ile ilgili eğitim alanında yapılmış olan üç lisansüstü tez, 25 makale, 10 bildirinin incelenmesini içermektedir. Tuna ve Saral (2018) yapmış oldukları çalışma sonucunda SOKÜM'ın korunması bağlamında milli duyarlılığın artırılması gerekliliği ve eğitim-öğretim kurumlarında sistemli ve planlı bir SOKÜM eğitimi verilerek bunun sağlanabileceğinin ortaya çıktığını göstermektedir.

\section{YÖNTEM}

Araştırmanın amacı, somut olmayan kültürel miras konusu ve unsurlarına ilişkin Türkiye'de yapılmış bilimsel yayınların bibliyometrik olarak incelenerek mevcut durumun değerlendirilmesidir. Bu kapsamda SOKÜM alanında lisansüstü tez, makale, bildiri türünde yapılmış çalışmaların çeşitli değişkenler açısından (yayın yılı, yayın dili, yazar bilgileri (cinsiyet, unvan, sayısı), yayın yeri, danışman bilgileri, yayın türü, yayın dili, çalışma konuları) ele alınması hedeflenmektedir. 
Araştırma evrenini YÖK Ulusal Tez Merkezi, Dergipark Akademik ve YÖK Akademik veri tabanındaki yer alan SOKÜM konulu bilimsel yayınlar (tez, makale, bildiri) oluşturmaktadır. Araştırmada veri toplama tekniği olarak nitel araştırma yöntemlerinden doküman-arşiv tarama tekniği kullanılarak ikincil veri kaynaklarından yararlanılmıştır. Konu ile ilgili çalışmaların tespit edilmesinde; lisansüstü tezler için YÖK Ulusal Tez Merkezi veri tabanında, makaleler için Dergipark Akademik ve YÖK Akademik veri tabanında, bildiriler için Türkiye'de periyodik olarak düzenlenen konuyla ilgili kongrelerden Uluslararası Kültürel Miras ve Turizm Kongresi (UKMTK) ve Uluslararası Turizm ve Kültürel Miras Kongresi (UTKMK) ile en köklü kongre geçmişine sahip olan Ulusal Turizm Kongresi (UTK) bildiriler kitaplarında "somut olmayan kültürel miras", "soküm" ve "intangible cultural heritage" söz öbekleri kullanılarak ilgili çalışmaların başlık ve anahtar kelimeleri üzerinden tarama yöntemi kullanılmıştır. 27-31 Ağustos 2020 tarihleri arasında yapılan taramalar sonucunda ulaşılan 54 lisansüstü tez, 136 makale ve 21 bildiri çalışması araştırmanın örneklemini oluşturmaktadır.

Erişim sağlanan yayınların değerlendirilmesinde sıklık ve yüzde analizi birlikte kullanılmış ve yayınlar, belirtilen bibliyometrik parametreler açısından çapraz tablolar halinde ele alınmıştır. Yayınların içeriklerine ve kapsamlarına ilişkin değerlendirmeler ise çalışma başlıkları üzerinde gerçekleştirilen veri görselleştirme analizi ile yapılmıştır. Verilerin görselleştirilmesinde interaktif bir yazılım olan Tableau kullanılmış ve araştırma verilerinin görselleştirilmesinde graph (area, bar, line, pie, text), packed bubbles, treemaps teknikleri tercih edilmiştir. Böylelikle SOKÜM alanında en çok hangi destinasyonların ön plana çıkartıldığı, hangi kültürel değerlerin veya unsurların ele alındığı, hangi konulara önem verildiği, hangi örneklem grupları üzerinde çalışmaların gerçekleştirildiği ve çalışma türü bakımından SOKÜM'ün hangi yönleri ile incelendiği grafiklerle daha anlaşılır hale getirilmiştir.

\section{BULGULAR}

Araştırma ile Türkiye' de 01 Eylül 2020 itibariyle somut olmayan kültürel miras konulu toplam 211 yayın yapıldığı, bunların tür bakımından \%64'ünün makale, \%26'sının lisansüstü tez ve \%10'unun bildiri olduğu belirlenmiştir (Grafik 1). Araştırma konusu ile ilgili ilk çalışmanın 2006 yılında yapıldığ 1 görülmektedir. Bu tarih Türkiye'nin 5448 sayılı "Somut Olmayan Kültürel Mirasın Korunması Sözleşmesinin Uygun Bulunduğuna Dair Kanun" ile UNESCO Somut Olmayan Kültürel Mirasın Korunması Sözleşmesi'nin tarafı olduğu 2006 yılı ile eşdeğerdir. SOKÜM ile ilgili yayınlar özellikle 2015 yılı sonrasında daha hızlı bir ivme ile artmaya başlamıştır. 


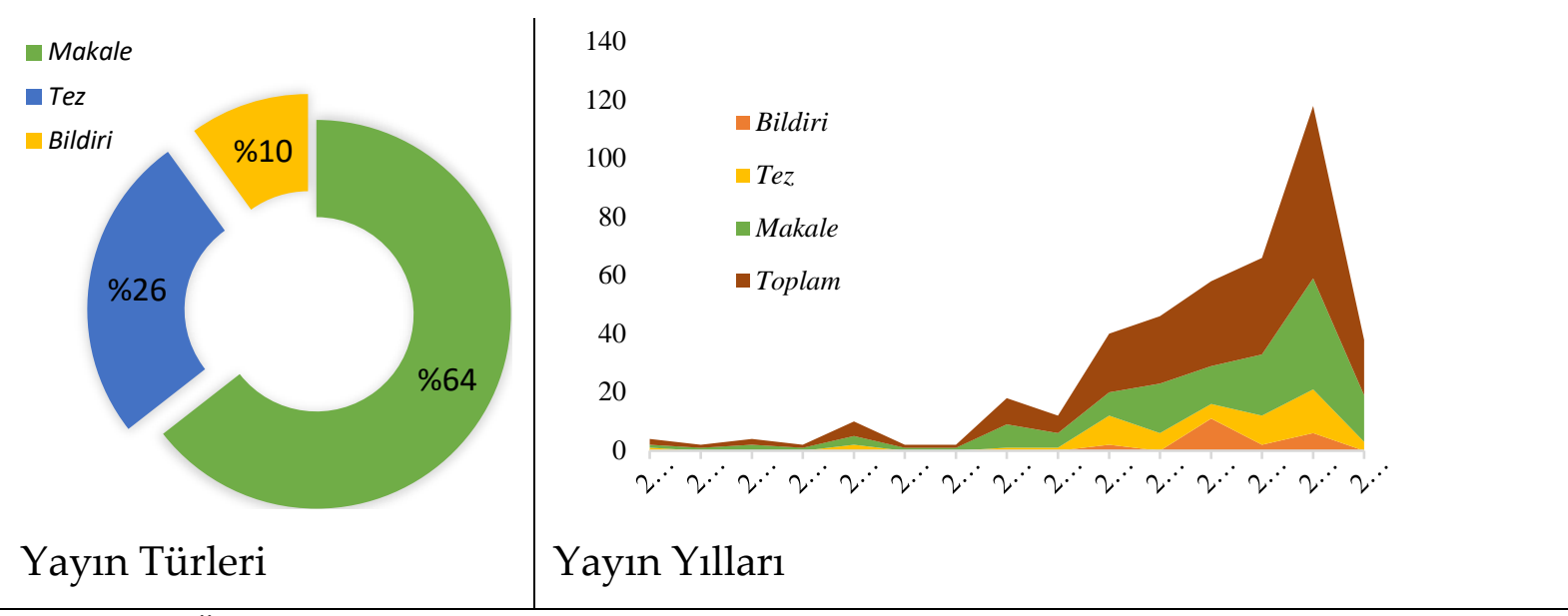

Grafik 1. SOKÜM konulu yayınların türlerine ve yıllara göre dağılımları

Araştırmada ilk olarak SOKÜM ile ilgili yayınların nitelikleri ve künye bilgileri türlerine göre ayrı ayrı ele alınmıştır. Bu kapsamda Tablo 1'de SOKÜM konulu lisansüstü tezlere ilişkin bulgulara yer verilmiştir. Tezlerin büyük çoğunluğu (43/54) yüksek lisans türünde ve tamamı Türkçe olarak yazılmıştır. Yazarların yarıdan fazlası kadın iken tezlere en fazla profesörler danışman öğretim üyesi olarak katkı sağlamıştır. Tezler en fazla Sosyal Bilimler Enstitüsü (38) bünyesinde ve Türk Halk Bilimi (14) ile Turizm İşletmeciliği (10) anabilim dallarında tamamlanmış olup çalışma konusu açısından da benzer şekilde en çok halk bilimi (18) ve turizm (11) alanlarında gerçekleştirilmiştir. Konu ile ilgili en fazla tez Gazi Üniversitesi yüksek lisans ve doktora öğrencileri tarafından yazılmış olup yıllara göre tezlerin dağılımın belirli bir standart taşımadığı ancak 2015 yılı ile SOKÜM alanına ilginin arttığ1 görülmektedir. Tezlerde ortalama 128,3 adet referans kaynağın kullanıldığı ve bunların yaklaşık üçte ikisinin Türkçe, üçte birinin ise yabancı dillerdeki yayınlardan oluştuğu tespit edilmiştir. Tezlerde üç ile beş arasında anahtar kelime(ler) kullanılmıştır.

Tablo 1. SOKÜM konulu lisansüstü tezlerin niteliklerine ve künye bilgilerine ilişkin bulgular

\begin{tabular}{|c|c|c|c|c|c|}
\hline Özellik & Türü & Sayı & Özellik & Türü & Sayı \\
\hline Tez & Yüksek Lisans & 43 & \multirow{3}{*}{$\begin{array}{l}\text { Kaynak } \\
\text { Sayısı }\end{array}$} & Türkçe & 84 \\
\hline Türü & Doktora & 11 & & Yabanc1 & 44,3 \\
\hline Yayın & Türkçe & 54 & & Toplam & 128,3 \\
\hline Dili & Yabanc1 & - & \multirow{3}{*}{$\begin{array}{l}\text { Danışman } \\
\text { Unvanı }\end{array}$} & Prof. Dr. & 28 \\
\hline \multirow{2}{*}{$\begin{array}{l}\text { Yazar } \\
\text { Cinsiyeti }\end{array}$} & Kadın & 34 & & Doç. Dr. & 17 \\
\hline & Erkek & 20 & & Dr. Öğr. Üyesi & 9 \\
\hline \multirow{5}{*}{ Üniversite } & Gazi & 14 & \multirow{5}{*}{ Yillar } & 2006 & 1 \\
\hline & Hacettepe & 4 & & 2010 & 2 \\
\hline & İstanbul, Muğla Sitkı Koçman & 3 & & 2013 & 1 \\
\hline & $\begin{array}{l}\text { Anadolu, Ankara Hacı Bayram Veli, Bartın, } \\
\text { Çukurova, Kastamonu, Süleyman Demirel }\end{array}$ & 2 & & 2014 & 1 \\
\hline & $\begin{array}{l}\text { Afyon Kocatepe, Akdeniz, Aksaray, Ankara, } \\
\text { Balıkesir, Erciyes, Eskişehir Osmangazi, } \\
\text { İstanbul Bilgi, Kadir Has, Karamanoğlu } \\
\text { Mehmet Bey, Kırıkkale, Koç, Mersin, Mimar }\end{array}$ & 1 & & 2015 & 10 \\
\hline
\end{tabular}




\begin{tabular}{|c|c|c|c|c|c|}
\hline & $\begin{array}{l}\text { Sinan Güzel Sanatlar, Selçuk, Yaşar, Yıldırım } \\
\text { Beyazıt, Yıldız Teknik }\end{array}$ & & & & \\
\hline \multirow{3}{*}{ Enstitü } & Sosyal Bilimler & 38 & & 2016 & 6 \\
\hline & Eğitim Bilimleri, Fen Bilimleri & 7 & & 2017 & 5 \\
\hline & Güzel Sanatlar, Türkiyat Araştırmaları & 1 & & 2018 & 10 \\
\hline \multirow{7}{*}{$\begin{array}{l}\text { Anabilim } \\
\text { Dalı }\end{array}$} & Türk Halk Bilimi & 14 & & 2019 & 15 \\
\hline & Turizm İşletmeciliği & 10 & & 2020 & 3 \\
\hline & Sosyal Bilimler ve Türkçe Eğitimi & 4 & \multirow{7}{*}{$\begin{array}{l}\text { Çalışma } \\
\text { Konu } \\
\text { Alanı }\end{array}$} & Halk Bilimi & 18 \\
\hline & İlköğretim, Mimarlık, Müzecilik & 3 & & Turizm & 11 \\
\hline & Kültür Varlıklarını Koruma, Türkçe Eğitimi & 2 & & Ĕ̆itim ve Öğretim & 10 \\
\hline & $\begin{array}{l}\text { Arkeoloji ve Sanat Tarihi, Halk Bilimi, İç } \\
\text { Mimarlık, İletişim, Kültürel Çalışmalar, } \\
\text { Matematik ve Fen Bilimleri Eğitimi, Peyzaj } \\
\text { Mimarlığı, Resim, Türk Halk Edebiyatı, } \\
\text { Yabancı Dil Olarak Yüksek Lisans Programı }\end{array}$ & 1 & & Mimarlık & 5 \\
\hline & Üç Adet & 12 & & Müzecilik & 3 \\
\hline \multirow{2}{*}{$\begin{array}{l}\text { Anahtar } \\
\text { Kelime } \\
\text { Sayısı }\end{array}$} & Dört Adet & 12 & & Edebiyat & 2 \\
\hline & Beş Adet & 29 & & $\begin{array}{lr}\text { Antropoloji, } & \text { El } \\
\text { Sanatları, Güzel } & \text { Ganatlar, İletişim, } \\
\text { Sanat Tarihi }\end{array}$ & 1 \\
\hline
\end{tabular}

Tablo 2'de SOKÜM konulu makalelerin nitelikleri ve künye bilgilerine ilişkin bulgulara yer verilmiştir. Makalelerin yayın dili bakımından incelendiğinde büyük çoğunluğu (118/136) Türkçe iken diğerlerinin ise İngilizce olarak yayınlandığı görülmektedir. Yazar sayısı açısından makalelerin, yarısından fazlası tek bir yazar tarafından; diğer kısmı ise iki veya üç yazarlı ortak çalışma olarak tamamlanmıştır. Sadece bir çalışma ise dört yazarlı olarak gerçekleştirilmiştir. Makalelere toplam 213 yazar katkı sağlarken unvana göre en fazla çalışma doktor öğretim üyeleri ile doçentler tarafından yapılmış olup öğretim elemanları ile öğrencilerin katkılarının ise önemli düzeyde olduğu görülmektedir.

Makalelerin çalışma konuları, tezlere kısmen benzer şekilde en çok turizm (36) ve halk bilimi (26) alanlarındadır. Konu ile ilgili yıllara göre makaleler 2006-2012 yılları arasında bir veya birkaç adet ile sınırlı iken 2013 yılı itibariyle SOKÜM alanına ilginin arttığ1 ve takip eden yıllarda yayın sayılarının çift haneli rakamlara ulaştığı görülmektedir. Makalelerde ortalama 28,5 adet referans kaynağın kullanıldı̆̆ı ve bunların üçte ikisinden fazlasının Türkçe, yaklaşık üçte birinin ise yabancı dillerdeki yayınlardan oluştuğu tespit edilmiştir. Makalelerde iki ile beş arasında anahtar kelime(ler) kullanılırken 31 çalışmada herhangi bir anahtar kelime bulgusuna rastlanmamıştır. 
Tablo 2. SOKÜM konulu makalelerin niteliklerine ve künye bilgilerine ilişkin bulgular

\begin{tabular}{|c|c|c|c|c|c|}
\hline Özellik & Türü & Sayı & Özellik & Türü & Say1 \\
\hline \multirow{15}{*}{ Yillar } & 2006 & 1 & \multirow{9}{*}{$\begin{array}{l}\text { Çalışma } \\
\text { Konu } \\
\text { Alanı }\end{array}$} & Turizm & 36 \\
\hline & 2007 & 1 & & Halk Bilimi & 26 \\
\hline & 2008 & 2 & & Sosyal & 22 \\
\hline & 2009 & 1 & & Eğitim & 20 \\
\hline & 2010 & 3 & & Mimarlık & 11 \\
\hline & 2011 & 1 & & Edebiyat & 4 \\
\hline & 2012 & 1 & & Folklor, Sanat Tarihi & 3 \\
\hline & 2013 & 8 & & Coğrafya, El Sanatları, Sosyoloji & 2 \\
\hline & 2014 & 5 & & $\begin{array}{l}\text { Güzel Sanatlar, İletişim, Müzecilik, Müzikoloji, } \\
\text { Tasarım }\end{array}$ & 1 \\
\hline & 2015 & 8 & \multirow{6}{*}{$\begin{array}{l}\text { Yazar } \\
\text { Unvanlar1 }\end{array}$} & Prof. Dr. & 19 \\
\hline & 2016 & 17 & & Doç. Dr. & 46 \\
\hline & 2017 & 13 & & Dr. Öğr. Üyesi & 52 \\
\hline & 2018 & 21 & & Arş. Gör. & 24 \\
\hline & 2019 & 38 & & Öğr. Gör. & 29 \\
\hline & 2020 & 16 & & Diğer (Öğrenci, Araştırmacı vb.) & 43 \\
\hline Yayın & Türkçe & 118 & \multirow{3}{*}{$\begin{array}{l}\text { Kaynak } \\
\text { Sayısı }\end{array}$} & Türkçe & 20,4 \\
\hline \multirow[t]{2}{*}{ Dili } & Yabanc1 & 18 & & Yabanc1 & 8,1 \\
\hline & İki Adet & 5 & & Toplam & 28,5 \\
\hline Anahtar & Üç Adet & 15 & \multirow{4}{*}{$\begin{array}{l}\text { Yazar } \\
\text { Sayıs1 }\end{array}$} & Tek Yazarlı & 71 \\
\hline Kelime & Dört Adet & 26 & & İki Yazarlı & 54 \\
\hline \multirow[t]{2}{*}{ Sayısı } & Beş Adet & 59 & & Üç Yazarlı & 10 \\
\hline & Belirtilmemiş & 31 & & Dört Yazarlı & 1 \\
\hline
\end{tabular}

Yayın türüne göre temel bulgularda son olarak SOKÜM konulu bildirilerin nitelikleri ve künye bilgilerine ilişkin bulgulara Tablo 3'te yer verilmiştir. Bildirilerin yayın dili bakımından neredeyse tamamı (20/21) Türkçe hazırlanmıştır. Yazar sayısı açısından makalelerin tersine bildirilerin, yarısından fazlasının en az iki yazarlı; yaklaşık üçte birinin ise tek yazarlı olarak tamamlandığı görülmektedir. Bildirilere toplam 41 yazar katkı sağlarken unvana göre en fazla çalışma öğretim görevlileri tarafından yapılmış olup beş lisansüstü öğrenci de yazar olarak katkı sağlamıştır. Bildirilerin kongre türü açısından dağılımı incelendiğinde, en fazla 16 adet ile 2016-2019 yılları arasında üç defa üst üste düzenlenen Uluslararası Turizm ve Kültürel Miras Kongresi'nde (UTKMK) yer aldığı belirlenmiştir. Ayrıca 2019'da düzenlenen 20. Ulusal Turizm Kongresi'nde (UTK) dört ve 2016-2019 yılları arasında üç defa üst üste düzenlenen Uluslararası Kültürel Miras ve Turizm Kongresi'nde (UKMTK) de bir adet ilgili alanda çalışmanın sunulmuştur. Bununla birlikte bildirilerde ortalama üç ile beş arasında anahtar kelime(ler) kullanıldığı tespit edilmiştir. 
Tablo 3. SOKÜM konulu bildirilerin niteliklerine ve künye bilgilerine ilişkin bulgular

\begin{tabular}{|c|c|c|c|c|c|}
\hline Özellik & Türü & Sayı & Özellik & Türü & Say1 \\
\hline \multirow{4}{*}{ Yillar } & 2015 & 2 & \multirow{2}{*}{$\begin{array}{l}\text { Yayın } \\
\text { Dili }\end{array}$} & Türkçe & 20 \\
\hline & 2017 & 11 & & Yabanci & 1 \\
\hline & 2018 & 2 & \multirow{3}{*}{$\begin{array}{l}\text { Kongre } \\
\text { Türü }\end{array}$} & UTKMK & 16 \\
\hline & 2019 & 6 & & UTK & 4 \\
\hline \multirow{4}{*}{$\begin{array}{l}\text { Yazar } \\
\text { Sayısı }\end{array}$} & Tek Yazarlı & 6 & & UKMTK & 1 \\
\hline & İki Yazarlı & 11 & \multirow{6}{*}{$\begin{array}{l}\text { Yazar } \\
\text { Unvanları }\end{array}$} & Prof. Dr. & 6 \\
\hline & Üç Yazarlı & 3 & & Doç. Dr. & 5 \\
\hline & Dört Yazarlı & 1 & & Dr. Öğr. Üyesi & 7 \\
\hline Anahtar & Üç Adet & 8 & & Arş. Gör. & 5 \\
\hline Kelime & Dört Adet & 8 & & Öğrr. Gör. & 13 \\
\hline Sayıs1 & Beş Adet & 5 & & Lisansüstü Öğrenci & 5 \\
\hline
\end{tabular}

Araştırmanın takip eden aşamasında, SOKÜM alanındaki yayınların başlıkları incelenmiş ve kullanılan sözcükler genelden özele çeşitli gruplandırmalarla görselleştirilmiştir. Bu kapsamda ilk olarak çalışma başlıklarında herhangi bir sınıflandırma yapılmadan Türkçe en fazla tekrar eden sözcükler analiz edilmiştir. Veri analizinde rakamlar, edat, bağlaç ve sözcük ekleri dikkate alınmamış olup toplamda 439 sözcük tespit edilmiştir. Sözcükler toplamda 1513 defa vurgulanmıştır. Tekrar eden, benzer sözcüklerin birleştirilmesi sonrasında en fazla kullanılan ilk 50 sözcük treemap tekniği ile Şekil 1'de yer verildiği gibi görselleştirilmiştir.

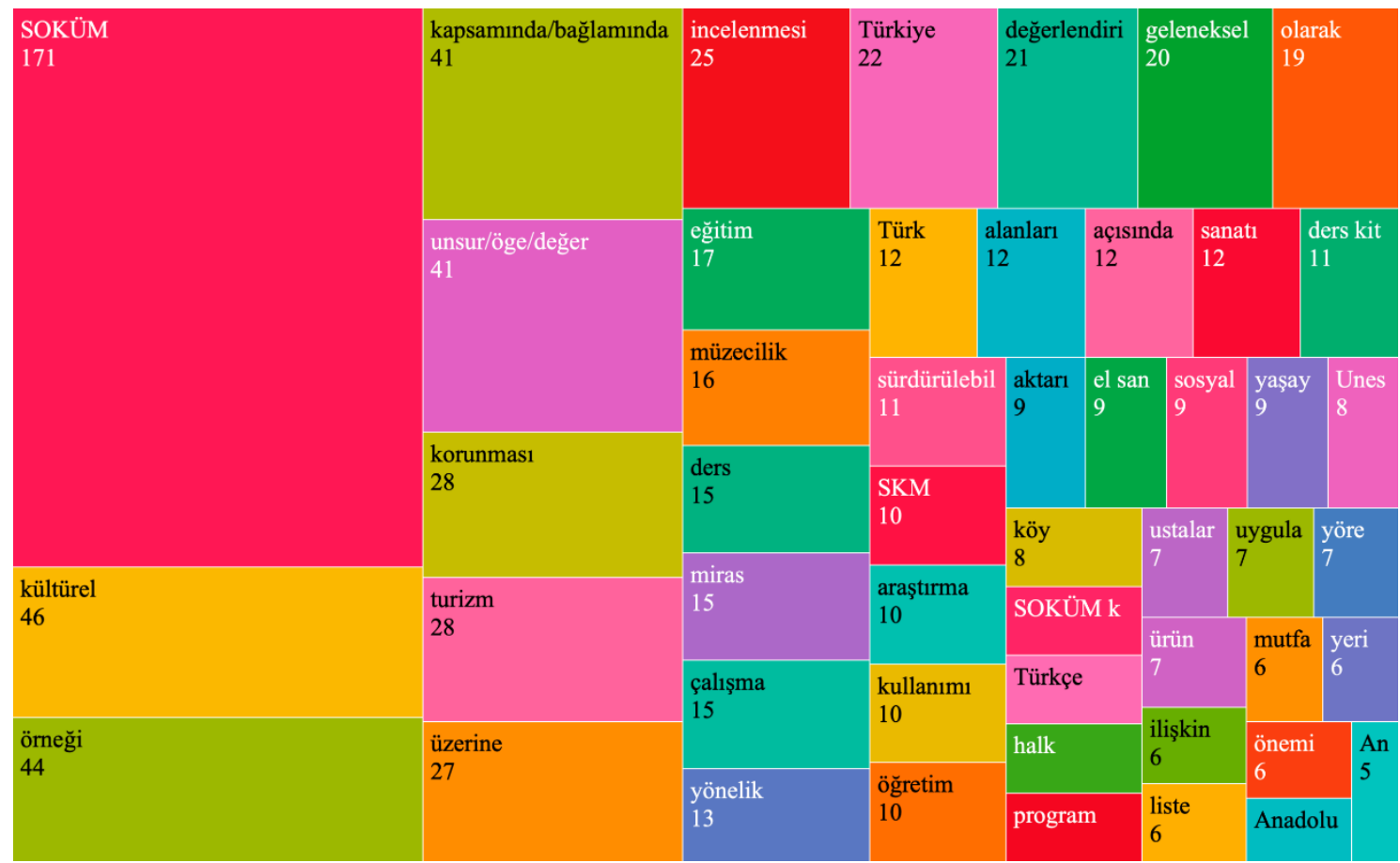

SOKÜM: Somut Olmayan Kültürel Miras, SKM: Somut Kültürel Miras, An: Ankara

Şekil 1. Çalışma başlıklarında en fazla kullanılan ilk 50 sözcük 
Çalışma başlıklarındaki sözcükler görsel analiz için bir diğer grup değişkeni olarak çalışmanın yapılacağı alanının bir göstergesi niteliğinde destinasyon(lar) kapsamında ele alınan yerleşim yerleri kendi içerisinde bir arada değerlendirilmiş ve görsel analizi yapılarak elde edilen bulgulara Grafik 2' de yer verilmiştir. Destinasyonlar text graph tekniği ile görselleştirilerek herhangi bir eleme yapılmadan tüm çalışma alanlarına yer verilmiştir. Ayrıca bar graph tekniği ile hangi destinasyonların kaç çalışmada ele alındığı vurgulanmıştır. Aynı il sınırları içerisinde yer alan farklı turizm merkezleri ayrı ayrı değerlendirilmiş, il ve ilçe adı olarak eş zamanlı vurgulanan destinasyonlar bir defa dikkate alınmış, tekrar eden çift sözcükler elenmiştir. Başlıklarda 75 farklı destinasyona ilişkin toplam 141 defa vurgu yapılmıştır. Bu destinasyonlar incelendiğinde çalışmaların gerek ülkesel-bölgesel olarak gerek il-ilçe-köy düzeyinde gerçekleştirildiği, bununla birlikte farklı kültür/milletlere ilişkin (Türk, Uygur, Osmanlı, Anadolu) odak unsurların ele alındığı görülmektedir.

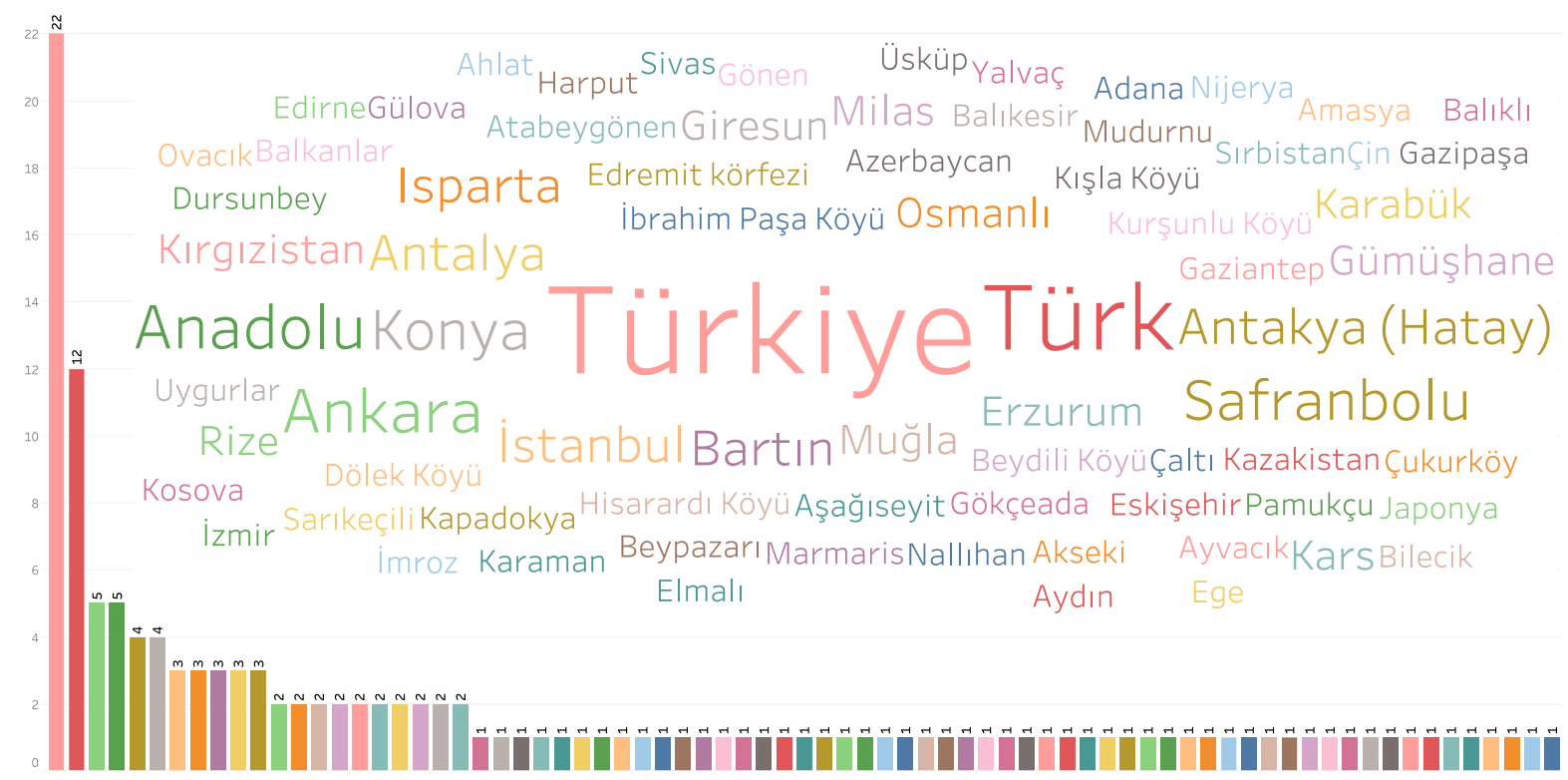

Grafik 2. SOKÜM destinasyonları

İkinci olarak, yayınlar içerdikleri SOKÜM değerleri/unsurları/öğeleri bakımından sınıflandırmaya tabi tutulmuş ve text graph tekniği ile elde edilen görsel haritaya Şekil 2'de ayrıntılı olarak yer verilmiştir. Yayınlarda 98 ayrı SOKÜM unsurunun 149 defa ele alındığı tespit edilmiştir. Bu unsurlar arasında sırasıyla en çok; el sanatları (9), Unesco (8), somut olmayan kültürel mirasın korunması sözleşmesi (7), mutfak (6), gastronomi (5) ve hamam (5) yer almaktadır. Bunların yanı sıra yaşayan insan hazineleri (3) ile birlikte insan unsuru olarak Ahmet Güldür (1), Aşık Mehmet Hicrani (1), Aşık Veysel (1), Kurt Ata (1), Nasreddin Hoca (1)'de, Tahsin Kalender (1) de çalışmalarda ele alınan SOKÜM değerleri olmuştur. 


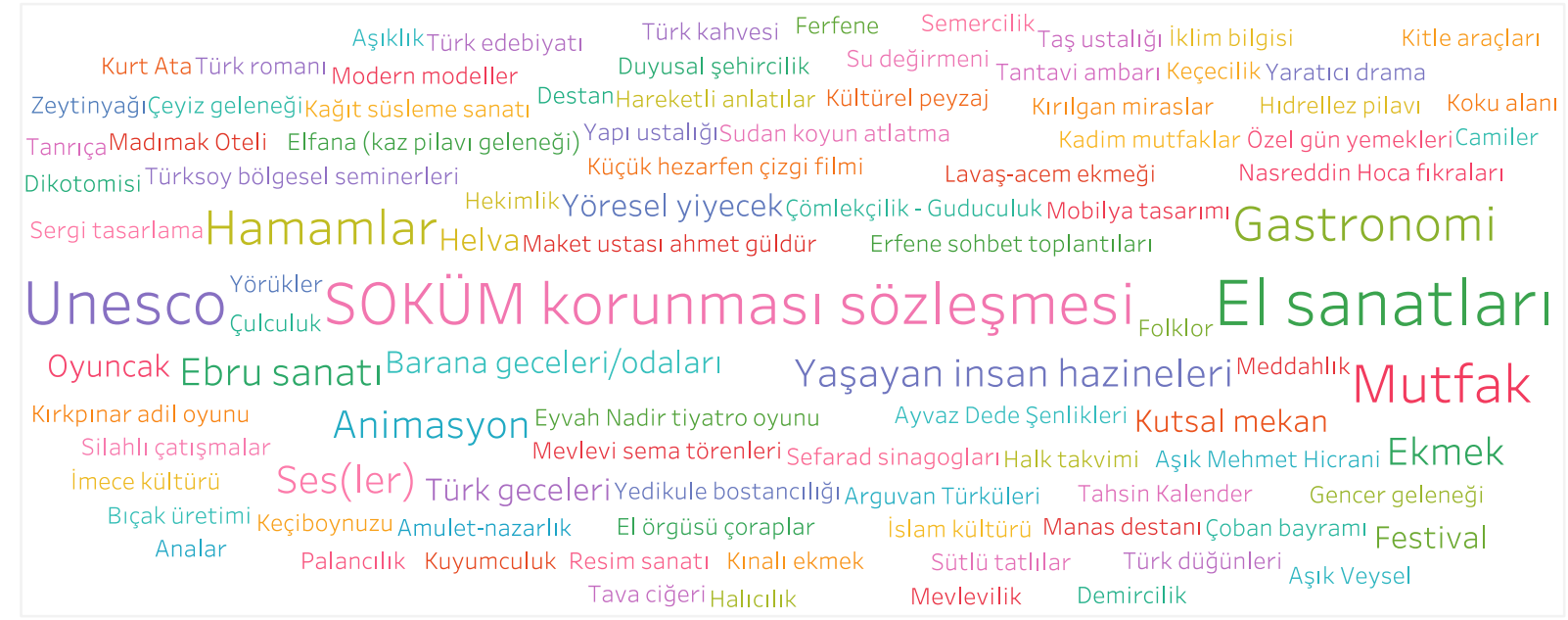

Şekil 2. SOKÜM değerleri ve unsurları

Araştırmada üçüncü olarak, çalışma yapılan örneklem gruplarına yönelik görsel harita hazırlanmış ve elde edilen bulgular Grafik 3'te ele alınmıştır. Çalışmalarda canlı (kişi veya bireyler) ve cansız (kurum, ögeler vd.) 80 ayrı örneklem grubuna 255 defa yer verilmiştir. Hazırlanan görsel haritada örneklem grubunun hem bütün içerisindeki payı packed bubbles tekniği, hem de örneklem grubu bazında çoktan aza doğru ilgili sözcüklerin niceliği shape line graph tekniği ile önem düzeyine göre vurgulanmaktadır. Çalışmalardaki örneklem grupları türlerine göre; mülki idare/coğrafi alanları (yöre, $i l$, şehir, ilçe, köy, saha, yer, mekân, coğrafya, destinasyon vb.), öğrenme (çocuk, ders, ders kitaplarl, dil, dönem, eğitim, ilkokul, kütüphane, lisans, ortaokul, örgün eğitim, plan, program, sinff, sosyal bilgiler, üniversite, yaygın eğitim), konum (çok uluslu, küresel, toplumsal, ulusal, uluslararası, yerel, yurtdışı), gerçek kişi (gençlik, gelecek nesil/kuşak halk, kadın, öğrenci, öğretmen, personel, turist, turist rehberleri, ustalar, yabancular), kurum/kuruluş (aile, endüstri, İl Kültür ve Turizm Müdürlüğ̈̈ (IKTM), üniversite, Kültür ve Turizm Bakanlı̆gr (KTB), Türkiye Büyük Millet Meclisi (TBMM)), yayın türü (afiş, belge, çizgi film, film, hikâye, proje, tiyatro) sanal (internet siteleri, online, webquest) şeklinde gruplandırılabilir.

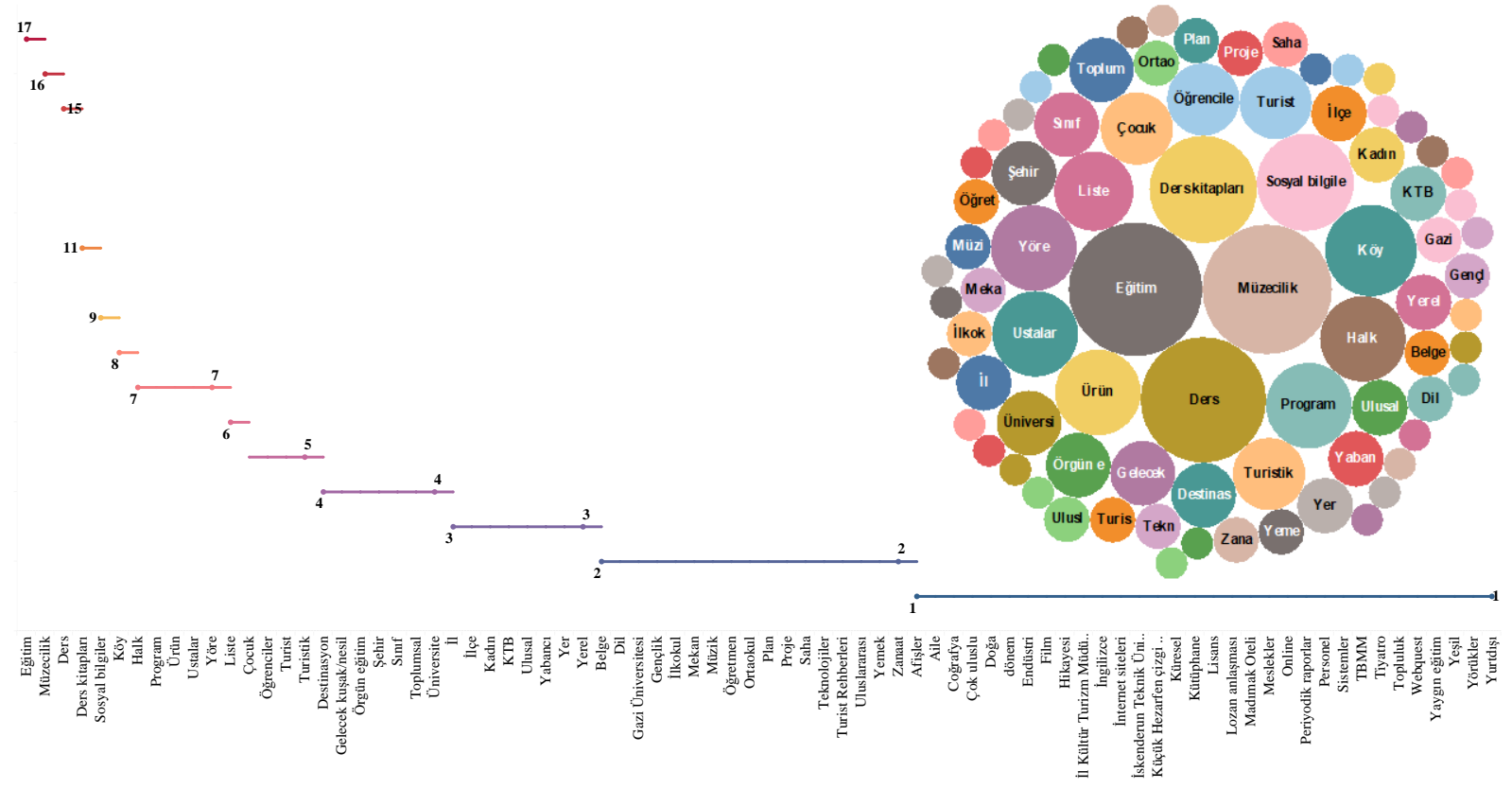

Grafik 3. Örneklem grubu 
Araştırmada son olarak yayınlarda SOKÜM ile ilgili hangi alanlarda incelemelerin yapıldığı, hangi yönlerinin ele alındığı ve vurgulandı̆̆ yürütebilmek amacıyla çalışma başlıklarındaki sözcükler çalışma türü bakımından görsel analize tabi tutularak değerlendirilmiştir. Elde edilen bulgulara ilişkin bar line grapgh ve treemap teknikleri ile hazırlanan görsel analiz haritası Grafik 4'te paylaşılmıştır. İncelenen çalışmalarda SOKÜM ile ilgili çalışma türünü betimleyen 49 sözcüğe ilişkin 319 vurgu yapıldığı belirlenmiştir. Tekrarlanan sözcüklerden en önemlisi 41 vurgu ile doğrudan öne çıkan SOKÜM listesinde olan veya olabilecek değerlere ilişkin çalışmalarda gerçekleştirilmiştir. Çalışmalarda SOKÜM'ün kendisine yönelik incelenmesi, değerlendirilmesi, kullanımı, alanları, önemi, tespiti, kaynakları, belirlenmesi, özellikleri gibi yönleri ele alınmıştır. Bu noktada en fazla; SOKÜM'ün korunması, eğitim ve müzecilik alanındaki yeri, sürdürülebilirliği, önemi-rolü, taşıyıcıları, deneyimi, tanıtımı-pazarlanması, geliştirilmesi, katkısı-etkisi-işlevi, çıktıları-çıkmazları, canlandırılması-aktifleştirilmesi gibi çeşitli yönleri dikkat alınarak çalışmalar şekillendirilmiştir.

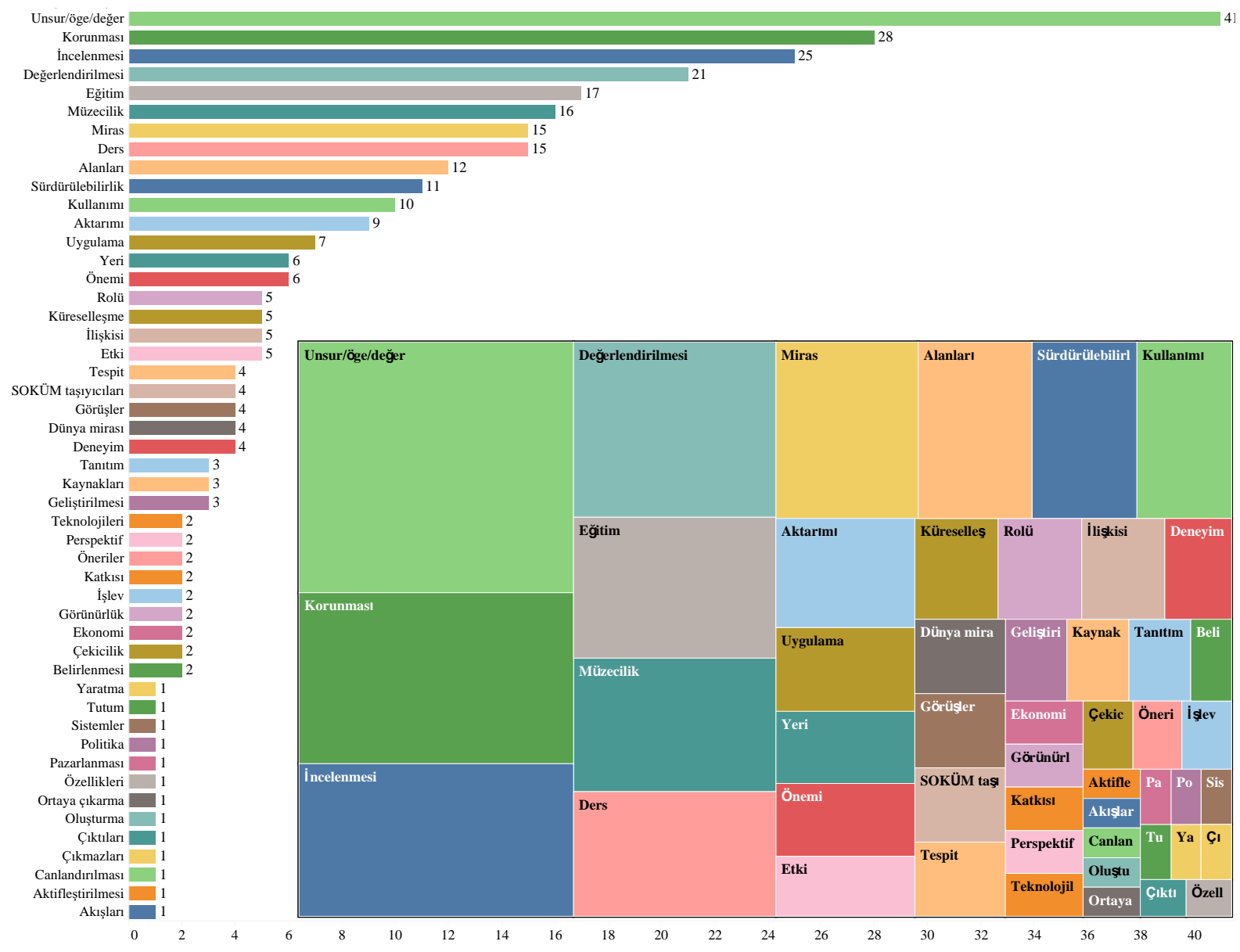

Grafik 4. Çalışma türü 


\section{SONUÇ, TARTIŞMA VE ÖNERILER}

Türkiye'de SOKÜM konulu yayınların görselleştirme tekniği ile farklı parametreler açısından ele alındığ 1 bu çalışmada önemli birtakım sonuçlara ulaşılmıştır. Bu sonuçlardan ilki 01 Eylül 2020 itibariyle Türkiye'de SOKÜM konulu toplam 211 yayının gerçekleştiği ve ilgili yayınların yarısından fazlasının makale türü olarak çalışıldığı, makale türünü lisansüstü tez ve bildirilerin izlediği görülmektedir. SOKÜM çalışmalarının yıllara göre dağılımına bakıldığında, çalışmaların Türkiye'nin UNESCO Somut Olmayan Kültürel Mirasın Korunması Sözleşmesi'nin tarafı olduğu 2006 yılında başladığı ve 2015 yılından itibaren ciddi bir artış sağladığ 1 görülmektedir. SOKÜM ile ilgili lisansüstü tez çalışmaları incelendiğinde, tezlerin önemli çoğunluğunun yüksek lisans türünde Türkçe yazılmış çalışmalar olduğu, tez danışmanlarının büyük bir bölümünün profesör danışman öğretim üyesi olduğu ve en fazla Gazi Üniversitesi yüksek lisans ve doktora öğrencileri tarafından yazıldığ1 görülmektedir. Yapılan tez çalışmalarının ağırlıklı olarak Sosyal Bilimler Enstitüsü bünyesinde, Türk Halk Bilimi ile Turizm İşletmeciliği Anabilim dallarında tamamlandığı, çalışma konusu bakımından da yine en çok halk bilimi ve turizm alanlarında gerçekleştiği görülmüştür. Yapılan lisansüstü tez çalışmalarının kaynaklarının üçte ikisinin Türkçe, üçte birinin ise yabancı dillerdeki yayınlardan oluştuğu tespit edilmiştir. Bu da konu ile ilgili yabancı kaynak yetersizliğinin bir göstergesi olabilir. Özellikle 2018 ve 2019 yıllarında ciddi bir ivme gösteren tez çalışmaları SOKÜM konusunun akademik anlamda giderek önem kazandı̆̆ını göstermektedir. Tez çalışmalarının önemli kısmının Profesör unvanına sahip danışmanlar tarafından yürütülmesi ilgili alanın akademik gelişimi adına önemli bir sonuç olarak görülebilir. Tez çalışmalarının halk bilimi ve turizm alanlarında yoğunlaşmış olması, özellikle SOKÜM unsurlarının halk bilimi çalışma konuları dâhilinde bulunması ile açılanabilirken, turizm açısından ise bakıldığında mevcut unsurların turistik çekicilikleri sebebiyle ele alındığı düşünülebilir.

SOKÜM ile ilgili makale çalışmaları incelendiğinde, makalelerin yayın dilinin büyük çoğunlukla Türkçe olduğu ve yarısından fazlasının tek yazarlı olduğu görülmektedir. Makalelere katkı sağlayan yazarların akademik unvan olarak doktor öğretim üyeleri ve doçentlerin yoğunlukta olduğu tespit edilmiştir. Makaleler çalışma konusu bazında incelendiğinde ise en çok turizm ve halk bilimi alanında yoğunlaştığı ve bu durumun tezlerle paralellik gösterdiği görülmektedir. Bununla birlikte, konunun eğitimden antropolojiye, turizmden mimarlığa, müzeciliğe kadar birçok farklı alanda çalışılması SOKÜM'ın birçok akademik alan için zengin bir araştırma konusu olduğunu göstermektedir. Benzer şekilde Çelebi vd., (2020) yapmış oldukları çalışmada Türkiye'de kültürel miras konusunun pek çok disiplin tarafından farklı bakış açıları ile incelendiğini ve bunun kültürel miras alanı ile ilgili disiplinlerarası anabilim dallarının akademik çalışmalarını da farklılaştıracağını belirtmektedir. Makalelerde kullanılan kaynakların yine tezler ile benzer şekilde Türkçe yayınların çoğunluğu oluşturduğu görülmektedir. SOKÜM ile ilgili bildiri çalışmaları incelendiğinde, 
bildirilerin neredeyse tamamının Türkçe hazırlandığı ve yazar sayısı bakımından makale çalışmalarının aksine yoğunlukla en az iki yazar tarafından hazırlandığı görülmektedir. Bildirilere katılımda en fazla yoğunluğun öğretim görevlileri tarafından olduğu görülmektedir. Bildirilerin yayın dilinin Türkçe olması ve ulusal düzeyde yayınlanması özellikle turistik çekicilik unsuru olarak görülen SOKÜM unsurlarının uluslararası boyutta tanıtımı için olumsuz bir durum olarak görülebilir. Bildirilerin sunulduğu kongre türüne bakıldığında, en fazla 2016-2019 yılları arasında düzenli olarak gerçekleştirilen Uluslararası Turizm ve Kültürel Miras Kongresi (UTKMK) 16 adet bildiri ile birinci sirada yer alırken onu 2019 y1lında 20.'si düzenlenen ve dört adet bildiri ile Ulusal Turizm Kongresi (UTK) takip etmektedir. SOKÜM ile ilgili yıllara göre dağılıma bakıldığında ilk bildirilerin 2015 yılında yapıldığ1 ve 18 Aralık 2015 tarihinde yürürlüğe giren “Akademik Teşvik Ödeneği Yönetmeliği" sonrası döneme denk gelen 2017, 2018, 2019 yıllarında ise SOKÜM alanına ilginin arttı̆̆ı görülebilmektedir. Kültürel miras temalı kongrelerin sayıca artması da SOKÜM alanında yapılan akademik çalışmaların artmasına bir neden olarak gösterilebilir.

Çalışmanın bir diğer araştırma konusu ise SOKÜM alanındaki yayınların başlıklarındaki sözcüklerin ele alınmasıdır. Bu bağlamda ilgili çalışmaların başlıklarında yer alan destinasyonlar incelendiğinde çalışmaların gerek ülkesel/bölgesel gerekse de il/ilçe/ köy düzeyinde gerçekleştirildiği, ayrıca farklı kültür ve milletlere vurgu yapıldığı tespit edilmiştir. Vurgu yapılan destinasyonlar incelendiğinde SOKÜM listesinde yer alan unsurlar ile özleşmiş (Isparta, Konya, Safranbolu, Bartın) ve Yaşayan İnsan Hazinesinde yer alan sanatçıların yaşadıkları destinasyonların varlığı yoğunlukla görülmektedir. Özellikle Ankara'da yer alan Gazi Üniversitesi Somut Olmayan Kültürel Miras Müzesi ve Ankara Somut Olmayan Kültürel Miras Müzesi'nin de bu destinasyona yoğunluğun sağlanmasına etki ettiği söylenebilir. Yayınların içerdikleri SOKÜM değerleri/unsurları/ögeleri bakımından sınıflandırmaya tabi tutulduğunda SOKÜM listesinde yer alan el sanatları, gastronomi vb. unsurların çalışmalarda en çok ele alınan değerler olduğu tespit edilmiştir. Yayınlardaki SOKÜM ile ilgili hangi alanlarda çalışmalar yapıldığına bakıldı̆̆ında ise genellikle çalışma alanlarının, SOKÜM'ın korunması, eğitim ve müzecilik alanındaki yeri, sürdürülebilirliği, önemi, deneyimi, tanıtım ve pazarlanması, geliştirilmesi katkısı-etkisi-işlevi ve canlandırılması-aktifleştirilmesi gibi yönlerinin doğrultusunda çalışmaların yoğunlaştığ tespit edilmektedir. Bu bağlamda özellikle sürdürülebilirlik, tanıtım ve pazarlama alanında yapılan çalışmalar bu değerlerin bir turistik çekicilik unsuru olabilmesi adına son derece önem arz etmektedir.

Doğrudan somut olmayan kültürel miras ile ilgili literatürde sadece Tuna ve Saral (2018) tarafından yapılan tek bir bibliyometrik çalışma yer almakta olup, ilgili çalışmada konunun sadece eğitim bilimleri alanında yapılan bilimsel araştırmalarla sınırlı tutulduğu görülmüştür. Bu çalışmada ise somut olmayan kültürel miras ile ilgili birçok farklı disiplinin (halk bilimi, turizm, eğitim vb.) araştırmaları farklı değişkenler bakımından ele alınmış ve böylece daha kapsamlı bir bibliyometrik analiz yapılması sağlanmıştır. Araştırma kapsamında ulaşılan önemli kazanımlara karşın bir takım 
temel sınırlılıklar da bulunmaktadır. İlk olarak, veri toplama kanalı olarak YÖK Ulusal Tez Merkezi, Dergipark Akademik ve YÖK Akademik veri tabanı ve araştırma alanı ile paralel nitelikli periyodik olarak düzenlenen üç turizm kongresi ile sınırlandırılmış, bu çalışmaların dişında akademik personele yönelik bilgi içerebilecek alanlar kapsam dışında yer almıştır. İkincisi, araştırmada "somut olmayan kültürel miras", "soküm" ve "intangible cultural heritage" söz öbekleri kullanılarak bilimsel yayınların başlık ve anahtar kelimeleri üzerinden tarama yöntemi kullanılarak konu ile ilgili çalışmaların tespit edilmesi hedeflenmiş, ilave söz öbekleri veya tarama alanları dikkate alınmamıştır. Son olarak, araştırma sonuçları Ağustos 2020 itibariyle geçerli olup sonuçlar verilerin toplanma sürecinde ilgili veri tabanındaki konuya ilişkin yer verilmiş araştırmalarla sınırlıdır. Bu kapsamda elde edilen verilerin/bilgilerin sınırlı olması nedeniyle çalışmada ele alınabilecek değişkenler ile bunlara yönelik gerçekleştirilen görsel analizler de bu sınırlar doğrultusunda değerlendirilebilmiştir. Dolayısıyla konu ile ilgili olarak ilerleyen dönemde gerçekleştirilecek çalışmalarda bu sınırlılıklar dikkate alınmalı ve mevcut araştırmanın sonuçları da bu sinırlılıklar kapsaminda değerlendirilmelidir.

Gelecekte SOKÜM alan yazınında yer alan uluslararası tez, makale ve bildiri çalışmaları incelenerek karşılaştırmalar yapılabilir. Bunun yanı sıra SOKÜM alanında yapılmış olan akademik çalışmaların farklı disiplinlerce ele alınması da ilerideki çalışmaların verimliliğini daha da artıracaktır (Harzing, 2010). Bilimsel bir çerçevede önemli gelişmeler sunan turizm alan yazınının bildiri, makale, tez türü gibi bilimsel çalışmaların yanı sıra bibliyometrik açıdan da araştırmalarla zenginleştirilmesi, turizmin akademik gelişmesi bakımından önerilebilir.

Hakem Değerlendirmesi: Dıs, bağımsız.

Teşekkür: Katkılarından dolayı hakemlere teşekkür ederiz.

Destek Bilgisi: Herhangi bir kurum ve/veya kuruluştan destek alınmamıştır.

Çıkar Çatışması: Yazarlar arasında çıkar çatışması yoktur.

Etik Onayı: Bu çalışmanın tüm hazırlanma süreçlerinde etik kurallara riayet edildiğini yazar(lar) beyan eder. Aksi bir durumun tespiti halinde Güncel Turizm Araştırmaları
Dergisi'nin hiçbir sorumluluğu olmayıp, tüm sorumluluk makale yazar(lar)ina aittir.

Bilgilendirilmiş Onam Formu: Tüm taraflar kendi rızaları ile çalışmaya dâhil olmuşlardır.

Etik Kurul Onayı: Çalışma kamuya açık ikincil verilerin kullanilmasiyla oluşturulmuştur.

Araştırmacıların Katkı Oranı: Yazarlar çalışmaya eşit oranda katkı sağlamıştır.

Veri Kullanılabilirlik Beyanı: Araştırma verileri paylaşılmamıştır.

\section{KAYNAKÇA}

Ağaoğlu, B. (1985). Sistematik Türkiye Turizm İşletmeciliği Bibliyografyası (1929-1984). Türkiye Turing ve Otomobil Kurumu Yayınları, İstanbul: Met $\backslash$ Er Yayınları.

Ahmad, Y. (2006). The Scope and Definition of Heritage: From Tangible to Intangible. International Journal of Heritage Studies, 12 (3), 292-300.

Al, U. (2008). Türkiye'nin Bilimsel Yayın Politikası: Atıf Dizinlerine Dayalı Bibliyometrik Bir Yaklaşım. (Yayınlanmamış Doktora Tezi), Hacettepe Üniversitesi, Ankara. 
Ar. H. (2015). Somut Olmayan Kültürel Mirasın Korunmasında Turist Rehberlerinin Rolü (Yayınlanmamış YL Tezi), Balıkesir Üniversitesi Sosyal Bilimler Enstitüsü Turizm İşletmeciliği ve Otelcilik Anabilim Dalı, Balıkesir.

Boas, F. (2012). Etnoloji Yöntemleri (N. Kabaklı çev.), İnsanbilim Dergisi, 1(2), 6-61.

Cole, F.J. ve Eales, N.B. (1917). The History of Comparative Anatomy: Part I. - A Statistical Analysis of the Literature. Science Progress (1916-1919), 11 (44), 578-596.

Çelebi, B., Çiftsüren, D. ve Dilek, S. E. (2020). Türkiye'de “Kültürel Miras” Konusunda Yapılan Tezlerin Bibliyometrik Analizi, Journal of Current Debates in Social Sciences, 3 (1), 10 19.

Demirel, Ö. ve Kaya, Z. (2009). Eğitim Bilimlerine Giriş. Ankara: Pegem Akademi Yayınları.

Durmuş, M.E. ve Kaya, S. (2018). Türkiye'de Vakıflar Üzerine Yapılmış Lisansüstü Tezlerin Bibliyometrik Analizi (1984-2016), Vakıflar Dergisi, (49), 131-146.

Hall, C.M. (1991). Tourism as the Subject of Post-Graduate Dissertations in Australia, Annals of Tourism Research, 18(3), 520-523.

Harzing, A.W. (2010). Citation Analysis Across Disciplines: The Impact of Different Data Sources and Citation Metrics. Research in International Management. https://harzing.com/publications/white-papers/citation-analysis-across-disciplines (Erişim Tarihi: 30.04.2020).

Hereduc. (2005). Heritage in the Classroom: A Practical Manuel for Teachers, http://www.hereduc.net $\backslash$ hereduc (Erişim Tarihi: 20.09.2020).

Hoffman, D.L. ve Holbrook, M.B. (1993). The Intellectual Structure of Consumer Research: A Bibliometric Study of Author Co-citations in the First 15 Years of the Journal of Consumer Research. Journal of Consumer Research, 19(4), 505-517.

Hotamışlı, M. ve Erdem, I. (2014). Muhasebe ve Finansman Dergisinde Yayınlanan Makalelerin Bibliyometrik Analizi, Muhasebe ve Finansman Dergisi, (63), 1-20.

Kozak, N. (2000). Türkiye'de Akademik Turizm Literatürünün Gelişim Süreci Üzerine Bir İnceleme. DAÜ: Turizm Araştırmaları Dergisi, 1(1), 15-55.

Kültür ve Turizm Bakanlığı. (KTB). (2020a). "Kültürel Miras" (https://www.ktb.gov.tr/TR96283/kulturel-miras.html). (Erişim Tarihi: 21.09.2020).

Kültür ve Turizm Bakanlı̆̆1. (KTB). (2020b). "Somut Olmayan Kültürel Miras" (https://aregem.ktb.gov.tr/TR-46095/somut-olmayan-kulturel-miras.html) (Erişim Tarihi: 21.09.2020).

Kültür ve Turizm Bakanlığı. (KTB). (2020c). "Somut Olmayan Kültürel Miras" (https://www.ktb.gov.tr/TR96254/kultur.html\#: :text=K\%C3\%BClt\%C3\%BCr\%2C\%20 bir\%20toplumu\%20di\%C4\%9Fer\%20toplumlardan,olu\%C5\%9Fturan\%20ya\%C5\%9Fa y\%C4\%B1\%C5\%9F\%20ve\%20d\%C3\%BC\%C5\%9F\%C3\%BCn\%C3\%BC\%C5\%9F\%20tar z\%C4\%B1d\%C4\%B1r.). (Erişim Tarihi: 21.09.2020).

Lawani, S.M. (1981). Bibliometrics: Its Theoretical Foundations, Methods and Applications. Libri, 31(1), 294-315.

Madran, E. ve Özgönül, N. (2005). Kültürel ve Doğal Değerlerin Korunması, Ankara: TMMOB Mimarlar Odası Yayınları. 
Polat, Z.A., Saraçoğlu, A. ve Duman, H. (2019). Harita Dergisinin Bibliyometrik Analizi, Harita Dergisi, 161, 46-56.

Potter, W.G. (1988). Of Marking Many Books There Is No End: Bibliometrics and Libraries, The Journal of Academic Librarianship, 14(4), 238-239.

Pritchard, A. (1969). Statistical Bibliography or Bibliometrics?, Journal of Documantation, 25(4), 348-349.

Sandıkc1, M., Boyraz, M., Mutlu, H. ve Gökçe, F. (2018). Gastronomi Araştırmaları Bibliyografyası Bildiri, Makale, Tez 2013-2017, Ankara: Detay Yayıncılık.

Toksöz, D. ve Birdir, K. (2016). Turizm Alan yazınında Kültürel Mirasla İlgili Çalışmaların Bibliyometrik Profili (2006-2015), I. Uluslararası Doğu Akdeniz Turizm Sempozyumu, V. Doğu Akdeniz Sempozyumu 22- 23 Nisan (76-88). Kuzey Kıbrıs.

Tuna, S.T. ve Saral, E. (2018). Somut Olmayan Kültürel Mirasın Korunması Bağlamında Türkiye'de Eğitim Alanında Yapılan Bilimsel Çalışmalar Üzerine Bir Bibliyografya Denemesi, Muğla Sıtkı Koçman Eğitim Fakültesi Dergisi, 5(1), 68- 78.

Türk Dil Kurumu (TDK). (2020a). “Kültür”, https://sozluk.gov.tr/ (Erişim Tarihi 21.09.2020).

Türk Dil Kurumu (TDK). (2020b). “Miras”, https://sozluk.gov.tr/ (Erişim Tarihi 10.11.2020). 